\title{
Inclusive Islamic Education In The Darul Amin Border of Tenggara Aceh
}

\author{
Hasan Asari', Abd. Mukti ${ }^{1}$ \& Syadidul Kahar ${ }^{2 *}$ \\ 1 Postgraduate of Universitas Islam Negeri Sumatera Utara, Medan, Indonesia \\ 2 Doctoral Student of Universitas Islam Negeri Sumatera Utara, Medan, Indonesia \\ *Corresponding Author: syadidulk@yahoo.com
}

\begin{abstract}
The problem that is analyzed in this article is about the concept and implementation of inclusive Islamic education in the Darul Amin Border Dayah in Southeast Aceh. This research is a qualitative study with a phenomenological approach by examining how the functions of the implementation of inclusive Islamic education in the Dayah Border Darul Amin Aceh Tenggara. Inclusive Islamic education in Dayah Border Darul Amin is integrated into the implementation of the dayah curriculum, both the dayah curriculum, the formal curriculum, the informal curriculum and the non-formal curriculum. Inclusive values instilled in dayah daily life are the values of tolerance, togetherness, mutual assistance, respect for differences and leadership based on Islamic values. The essence of inclusive Islamic education in the Darul Amin Border Dayah is the leader of the ummah and the generation of Muslim believers who are highly virtuous, knowledgeable, free-thinking and devoted to society.
\end{abstract}

Keywords: islamic education; dayah inclusive

\section{Introduction}

Islamic education with its historical journey has given birth to a variety of knowledge with all its problems so that the pros and cons of this new knowledge occur. This is because basically Islamic education provides solutions to changes in life that are being lived by humans, of course these changes require an integrative stage process. The aim is to be able to give its own meaning and color to Islamic education itself, this is due to various kinds of influences from the journey of human life. Thus, students are able to show the value of their nature as humans, because basically education is the main thing that humans must get and do as a direction and guidance for the journey of life itself. So it is not surprising that the real world today will never stop to always talk about education from various perspectives and the problems that surround it.

For this reason, Islamic education is currently in the stage of determining its own destiny and future. The reality of this problem can be seen from several aspects related to the slightest problems of Islamic education itself, including the existence of a dichotomy in education, curriculum development and implementation, human resource development for educators and so on. The real principles of education that must be enforced are independence, democracy, and justice. Regarding this, our Master Muhammad[s]. Given the mandate by being sent by Allah SWT to teach and educate people as a whole to become servants of Allah with character and grace for the entire universe. As the word of Allah Q.S. Al Anbiya 21: 107.

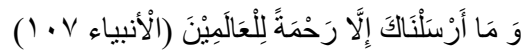

Meaning: And we did not send you, but to be a mercy for the universe.

Based on the description of the verse above, it can be understood that Allah Ta'ala reported that Muhammad SAW sent as a blessing for the universe. The journey of the Prophet's da'wah in teaching Islam to his people, then the span of time that Islamic education continues. This means that the teachings of Islam have grown and developed to other parts of the world during the preaching process. The growth and development of the teachings of Islam to other areas of the world, thus Islamic education follows. As a messenger for all humans who carry the mandate of happy news for those who carry out the teachings conveyed by the Prophet and as a warning for those who do not believe in the Prophet. The existence of people around the world is certainly different, these differences have the same rights in accepting Islamic teachings. 
Historically, Aceh was the initial gateway for the development of Islamic teachings in the archipelago. So it becomes a reality that the existence of Islam in Aceh in particular is carried out in a peaceful and sustainable manner without occupation of territory by military forces. The spread of Islam in the archipelago in general was spread to a certain extent by traders, religious teachers (da'i) and Sufi nomads. People who are involved in the first da'wah activities do not have any tendency other than to be responsible for fulfilling obligations without strings attached, so that their names pass away, without leaving history and personal achievements that are deliberately made for them to dedicate their role. In addition, the archipelago is very broad with different conditions and situations. Therefore, it is natural that there are differences of opinion about when, from where and where Islam first came to the archipelago (Sunanto, 2005: 7). Aceh, which is the center of Islamic civilization in Southeast Asia, has a much grounded existence. This is because the existence of Islam in the midst of society has become a culture or people's religion and as the official religion of the kingdom which functions as the foundation and principle of fostering adat. Therefore, the culture and character of a polite society, because through comprehensive guidance of Islamic religious teachings, the Acehnese people become a civil society that is honest, just, ihklas and dares to uphold the truth and carry all forms of immorality and cruelty.

Dayah education, which has become a tradition for the people of Aceh, is an institution that is fully implemented by the community and financed by the local community's self-help. Along with its historical journey, the government's participation in the development of Islamic educational institutions was more intense. Dayah development is carried out by established scholars and has permission from their teachers, the development is independent and involves the community and this is an educational tradition that is entirely carried out by communities inherited from their ancestors. The continuity of this dayah model of education is solely due to its deep cultural roots in the life of the Acehnese people. In line with the development of the dayah itself which has given birth to scholars who have been active throughout Aceh in particular and the archipelago and internationally in general, it has given its own color to the dayah itself. Finally, the interest in dayah was no longer for the Acehnese alone but outside Aceh so that the students came from various regions. On the other hand, new dayahs were established in various regions including Southeast Aceh, which is one of Aceh's multicultural districts, both ethnic and religious. This is what makes it unique because the existence of a dayah that is identical to its Acehan is inclusive.

As God's creatures, students who are educated humans have various differences between one individual and another. This fact shows that humans as individuals are naturally different, so individual differences are unique. Based on this, education should be directed at guiding and developing the potential of students optimally. But in this case, so as not to ignore the individual difference factors in shaping students in the direction they aspire to. Students must strive and provide an environment to develop their talents and abilities optimally. Each individual student has different talents and abilities and therefore requires different education (Munandar, 1999: 6).

Inclusion itself means the integration of children into regular educational programs (Smith, 2012: 45). Meanwhile, inclusive education itself is an education system that serves and provides opportunities for all children to study together in public schools by paying attention to diversity and individual needs, so that children's potential can develop optimally (Indiyanto, 2013: 9). So, in this case the concept of education offered involves students to study together which makes them part of the school community so as to create a conducive learning atmosphere. The goal is to provide the widest possible opportunity for all students so as to realize the provision of education that respects diversity and is not discriminatory for all students (Kustawan, 2012: 2). Basically, inclusive education in religious education institutions is important to be implemented, the goal is to enlighten students so that they can emulate the nature of God Almighty. So that the reality of diversity does not worry one religious group, but can educate people as servants of God who are wise and respectful of each other.

A community environment in implementing inclusive education has the belief that living and learning together is the best way of life. So the implementation of an inclusive education system is one of the conditions that must be met to build an inclusive society order. This order is the formation of a society that respects each other and upholds the values of diversity as part of the reality of life. The importance of this inclusiveness is faced with a pluralistic human life that is accompanied by the times, sciences and contemporary issues such as universal humanity, pluralism and others. An inclusive Islamic education institution that is offered is able to bring people into the new millennium with an open and confident attitude (Wijdan, 2007: 139). This is where there needs to be an educational awareness that is more inculcated in open attitudes and avoids egocentric attitudes. Education with a model like this can be adapted from inclusive Islamic thought. Inclusive values are implied in education in order to generate a learning that prioritizes shared truth and does not favor one group.

Based on this description, Dayah Darul Amin is a dayah whose students and teachers come from various cultural ethnicities, both Batak, Karo, Java, Aceh, Pak-Pak and others. On the other hand, the dayah 
community is also multicultural and some even have different religions. What's more, bordering Karo land, here is where there is a unique aspect of dayah development. On the one hand, dayah is increasingly in demand from various regions of Southeast Aceh, as well as Tanah Karo and Dairi. On the other hand, the existence of the dayah received support from various parties, such as when arriving at the border with Southeast Aceh, when someone asked about Daru Amin's address to the border community even though he was not Muslim, they showed it kindly. Thus this article describes how the implementation of inclusive Islamic education in Dayah Darul Amin Aceh Tenggara.

\section{Research Method}

The research used in this research is qualitative research using a phenomenological approach. The purpose of using this method is to find the basic and essential things of phenomena and reality (Moleong, 2011). Data collection techniques used in this study in obtaining data to be analyzed were using active participatory observation, semi-structured interviews with the leaders of the boarding school, the ustadz and ustadzah, the Darul Amin Border Dayah students of Southeast Aceh. As secondary material is a documentary study, namely administrative documents, pesantre guidelines, AD and ART, schedule of activities and other documents that are directly and indirectly related to the implementation of inclusive Islamic education. Meanwhile, to analyze the data in this study, it is used by unitizing, categorizing and interpreting the data (Miles and Huberman, 1994). The data validity test was carried out by extending the participation in the field with the academic community of the pesantren, persistence in observations by participating in various training activities, triangulating the results of documentation, interviews and observations of conditions in the Darul Amin Border Dayah, Aceh Tenggara.

\section{Results and Discussion}

\subsection{Results}

Darul Amin is an Islamic boarding school/dayah educational institution located at Lawe Pakam, the border of North Sumatra and Aceh Tenggara, which was founded in 1998. At the beginning of its establishment, the location of Dayah Border Darul Amin is located on the border of Aceh province with North Sumatra Province, Tanah Karo district, 31, $8 \mathrm{~km}$ to Kutacane, the capital of Southeast Aceh Regency, $176 \mathrm{~km}$ to Medan, the capital of North Sumatra Province, and $762 \mathrm{~km}$ to Banda Aceh, the capital of Aceh Province. Darul Amin Border Dayah is present in the midst of the people of Southeast Aceh in accordance with the community's need for quality and affordable educational facilities. The pesantren / Dayah are under the umbrella of the Darul Amin Foundation. After going through 10 early years without any significant progress, in early 2008 the Chairman of the Foundation as well as the Regent of Southeast Aceh Ir. H. Hasanuddin B, MM, appointed Drs. H. Muchlisin Desky, MM as the new leader at the same time initiating reforms in the structural ranks and changes in the education management system. In 2010, Darul Amin became one of the Islamic boarding schools/Dayahs under the auspices of the Aceh Province Dayah Education Service (DPD) and changed its name to Darul Amin Border Dayah. This further strengthens Darul Amin as a superior Islamic boarding school/dayah with a strategic role as a stronghold of Muslim faith in the border area of Aceh-North Sumatra province.

With the support of competent resources in various lines, Darul Amin continues to innovate and transform changes in a positive direction. Among the innovations made were the construction of a football field, comparative studies abroad, training in business unit management for teachers from abroad, strengthening Islamic boarding school business units and so on. The achievements in recent years include first place in the cleanest and healthiest Islamic boarding schools in the province, environmental ambassadors, and others. Currently, the prospects for Darul Amin graduates are scattered in various universities, both public and private, and even abroad, followed by a series of achievements in their respective fields. In accordance with the demands of the times and developments, Darul Amin feels he is responsible for serving the younger generation. Darul Amin emphasizes the values of the five souls of sincerity, simplicity, independence, ukhuwwah Islamiyah and freedom. Efforts to improve education management by implementing continuous quality improvement have increasingly made Darul Amin a potential community destination in terms of Islamic education.

To focus on the achievement of the goals of Islamic education at the Darul Amin Border Dayah, the vision achieved is as an educational institution that produces cadres of community leaders who educate and develop a generation of Muslim believers who are highly virtuous, healthy, knowledgeable, free-minded and devoted to society. As a modern-based dayah, the curriculum implemented in the Darul Amin Border Dayah is: 
a. Dayah Education: Kulliyatu Mu'allimin al Islamiyah (KMI)

b. Formal Education: Curriculum 2013

c. Non-Formal Education: Jam'iyyatul Qurra, Tahfidz Qur'an, Study of the turats book, Santri Organization

d. Informal Education: Scouts, football, cooking (girls), nasyid, martial arts (tapak Suci), gymnastics, painting, calligraphy, fardhu kifayah jenazah, comparative studies (rihlah iqtishadiyah), teaching practice (amaliyyatu-l-tadris), fish farming catfish, gardening.

The achievements in the last few years include in 2018 the first winner of the cleanest Islamic boarding school in Southeast Aceh Regency. Currently, the prospects for Darul Amin graduates are scattered in various universities, both public and private, and even abroad, followed by a series of achievements in their respective fields.

In accordance with the demands of the times and developments, Darul Amin feels he is responsible for serving the younger generation. Darul Amin emphasizes the values of the five souls of sincerity, simplicity, independence, ukhuwwah Islamiyah and freedom. Efforts to improve education management by implementing continuous quality improvement have increasingly made Darul Amin a potential community destination in terms of Islamic education. This year's Darul Amin Border Dayah in admission of new students has increased significantly. Data on santri in 2019 were 622 people, this number is included in the largest group in Southeast Aceh Regency. By looking at the addition of new students who are currently available and do not have sufficient santri dining rooms, the Darul Amin Border Dayah really needs a new santri dining room to improve representative infrastructure suggestions.

Basically, the Darul Amin Foundation is better known as the border dayah because this foundation is one of the four border dayahs of Aceh. Based on the managers who have been elected, they will work for 5 years, unless there is a reason or a violation is committed, then a change of management occurs. The delegation of duties from the foundation was officially carried out through an inauguration ceremony chaired by Raisman, their election was the trust of Raisman as the person in charge of providing education under the auspices of the Darul Amin Foundation. Apart from being managerial officers, they are also on the teaching board or who are still actively teaching. Basically, the education and teaching system at the Darul Amin foundation generally follows the Gontor pesantren system. The interesting thing here is that there is a devotion teacher from the Gontor modern boarding school, so that the Darul Amin foundation is very thick with multiculturalism and a mix of foreign cultures. After being elected, the management of the foundation and coordinated by each representative to conduct a work meeting. After finishing with the Raisin assistant, then a work meeting is held in each division, while the planning is carried out under the deputy head of the dayah sector in collaboration with the heads of SMP and MA.

To improve the quality of education, the planning carried out contains points from the mission and makes operational steps in achieving the vision. The emphasis is on the learning and managerial process of each educational institution managed by the Darul Amin Foundation. Thus, improving the quality of education at the Darul Amin foundation is in line with the vision and objectives of the Darul Amin Foundation. The combination of these three things can form a superior student personality. Such as the main profile of graduates who have healthy and good personalities, have extensive and creative and innovative knowledge in their fields and have responsibility for carrying out tasks based on scientific ethics of Islamic education and the teaching profession..

\subsection{Discussions}

\subsubsection{Dayah in Community Social Review}

Dayah in Aceh is an educational institution that enables the community to build and develop the dayah itself. So in this case, the community has a role in contributing to the dayah itself. In general, behavior in society is determined by the internal structure of something outside of itself which can only influence and the type of relationship is influence-influencing, and still the determination is the internal structure. The integrity of the dayah institutional system will also be patterned from simple behavior in speaking and acting. So in this case, the social system is always marked by the existence of a connection between the components that make up the structure of society, there is a relationship which is the constitution of the system organization, and some are not part of the organization. If this linkage does not exist, the system organization will experience disintegration and will no longer be the same system. When the dayah is in a particular community system such as an inclusive basis, it will have an influence on the dayah itself. The concept of dayah has been understood traditionally and with acehan, so with a pattern that shapes society, it requires an educational institution that meets the needs of the community. So in Aceh, it has divided the dayah into three, namely traditional dayah, integrated dayah and dayah tahfiz. 
Change and development of the dayah with the influence of the social development of the community, in dayah educational institutions, it is inseparable from efforts to change the education system in the dayah. Changes in the system include changes in methodologies and approaches as well as in the form of educational institutions, in which dayah in addition to adopting a better contemporary approach by not leaving the old approaches and systems that are still relevant to the development of education today. Such an idea is a strong legality of all reconstruction efforts towards education in dayah. The freedom to form a dayah style is a necessity that cannot be avoided, as long as this change is inseparable from the concept of alashlah (better). Likewise, when the dayah is required to make changes as a consequence of the progress of the modern world, the alashlah aspect is the key word that must be held.

The modern dayah constructed in Dayah Darul Amin Aceh Tenggara is responsive to the changes and guidance of the times, is future-minded and harmonizes with the social conditions of a multicultural society, always prioritizes the principle of effectiveness and efficiency so that the existence of dayah becomes a community need. this is where the uniqueness of the Darul Amin Border Dayah. The concept of dayah is still carried out by teaching the turats book, on the other hand it is more priority to modern concepts and makes diversity the main value in strengthening Islamic values towards students. This can be seen from the absence of various customary and cultural activities at the annual rally or joyous arena and the perpetrators are students from various ethnic cultural backgrounds. Likewise the ustaz who teach consists of various ethnic cultures, but in the learning process they do not favoritism and those who become outstanding students or overall champions are from groups who are not the majority of the local population such as the Alas tribe.

The social environment of the people of Aceh Tenggara, Tanah Karo, Dairi and Gayo Lues who are generally Dayah Darul Amin students and also from Medan, Java, Lampung and Mandailing besides the dayah environment is inclusive, where the students live is also heterogeneous. So indirectly this nature is the teacher of man himself, the Islamic view of nature, man and society, even the whole reality of nature leads to the emergence of problems regarding the view of life, its end is also a subsystem. Through the potential possessed by students who are fostered to face nature, they always try to be side by side with nature, not eliminate or change. Of course in this case the basic thinking process used, the ideas of these thoughts are made in one concept and outlined in a rule called education. This is where the role of the Darul Amin Border Dayah to instill inclusive values with ideas based on the Koran and hadith, so that the inclusive style implemented has its own color. So in this case, the Darul Amin Border Dayah gives freedom to all dayah citizens to participate in activities in the dayah and even gives permission to participate in social activities in the dayah and santri environment.

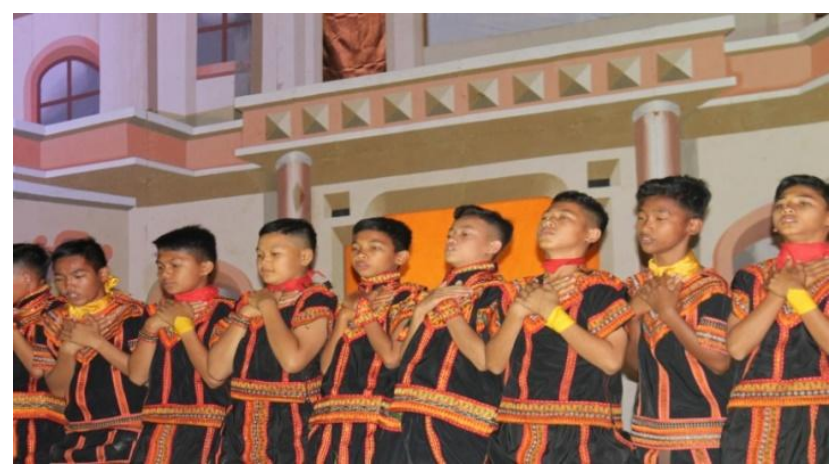

Figure 1. One of the performances of Santri Dayah Border Darul Amin dance from Gayo

\subsubsection{The Darul Amin Border Dayah Education Curriculum, Inclusive Perspective}

Formally, inclusive education is not constructed by standard rules, but in its implementation it can be seen in learning activities both formal and informal. All students come from different backgrounds but in the implementation of the curriculum they still receive the same treatment, such as in the use of English and Arabic. The curriculum itself is the components of the internal structure in determining an education system to be implemented. The curriculum is also a tool to achieve educational goals as well as guidelines and teaching concepts at all types and levels of education, including dayah education. The whole dayah curriculum method is in the form of knowledge and experience that is systematically provided to students in order to achieve educational goals. The curriculum used in dayah differs between traditional dayah, dayah tahfiz and modern dayah. The Darul Amin Border Dayah itself has a complex curriculum as follows:

a. Dayah Education: Kulliyatu Mu'allimin al-Islamiyah (KMI)

b. Formal Education: Curriculum 2013

c. Non-Formal Education: Jam'iyyatul Qurra, Tahfidz Qur'an, Study of the turats book, Santri Organization

d. Informal Education: Scouts, football, cooking (girls), nasyid, martial arts (tapak Suci), gymnastics, 
painting, calligraphy, fardhu kifayah jenazah, comparative studies (rihlah iqtishadiyah), teaching practice (amaliyyatu-l-tadris), fish farming catfish, gardening.

Basically, students are very much determined by the students who are actually lived as a guide for their attitudes and behavior, both in their relationship with themselves and God Almighty, the social life of the community and the natural surroundings. Based on this, the santri's behavior tends to be related to inclusive values, so these values can sharpen the quality of the spiritual intelligence of the students. The goal is that students can form good morals and respect their community. Therefore, all dayah residents, especially those with spiritual values themselves, are objectified into the learning process both formal and informal in the dayah environment. The spiritual values in question are honesty in action, togetherness, and social solidarity, so these values occupy the top position in the goals of inclusive Islamic education. Its implementation at the Dayah Perbaasan Darul Amin will motivate students to improve the quality of their spiritual and emotional intelligence.

In general, the implementation of inclusive Islamic education in the Border Dayah Darul Amin environment faces three main challenges, namely religion, ethnicity, and tolerance. These three things indicate that they are still susceptible to mutual suspicion and mutual feeling of being threatened by each other which then leads to tension and acts of violence. So, one of the effective efforts for now to achieve harmonious relations is through inclusive education activities. When viewed in the Darul Amin Border Dayah concept, the inclusive value developed is the nature of understanding the wisdom, awareness, attitudes, and behavior (mode of action) of students towards diversity both in the dayah environment and where they live. In its implementation, all components of the Darul Amin Border Dayah work together to support each other, such as the use of Arabic and English for all students without dividing the tribes that do not follow these rules and may not use regional languages in the dayah complex except on days. Certain so that the students are not rigid and remain relaxed with their culture. When there is a cultural performance activity, then in its implementation it is not only for the culture of the students, but whoever is involved in the activity. Likewise the dormitory, the students are not only one adat in one room but they are combined. So in this case, it appears that the students are taught and accustomed to living in harmony with differences and making differences as a treasure trove for the students.

Based on these descriptions, both in the dayah curriculum, formal, informal and non-formal, inclusive elements form the basis for its implementation for students. These inclusive values are tolerance, respect for differences and make differences a treasure trove of knowledge. Thus, reforming the curriculum that was formed by the teachers and Islamic education with an inclusive perspective aims to strengthen the beliefs of Islamic teachings and practice religious teachings in life. At the same time, emphasizing the appreciation of social values that come from religion so as to encourage tolerance and mutual respect with differences and cooperation in solving problems in various aspects of life as a form of practicing religious teachings. Inclusive Islamic religious education respects the diversity of religions, cultures, ethnicities and languages while adhering to the principles of their respective religions. The efforts made to give birth to this concept were made through the existing Islamic religious education curriculum. So in this case, it is necessary to reinterpret the existing holy texts as a manifestation of religious concern for social reality.

Basically, in the context of Islamic education, Islamic education itself is a transformation and internalization of the basic values and ideals of Islamic teachings that seek to accentuate aspects of differences and disparities in humanity in its broad context. Thus, these differences must be accepted with full wisdom and grace in the midst of plural humanity in all its dimensions in order to create a just life order. So in this case, inclusive Islamic religious education is a comprehensive effort in preventing conflicts between religions, preventing religious radicalism, while at the same time fostering a positive appreciative attitude towards plurality in any dimension and perspective. So, the vision and mission of an educational institution must be in line with inclusive values to realize religion in a more polite, dialogical, appreciative side to plurality and care for transformative communal life problems for students.

The education curriculum in the Darul Amin Border Dayah as a whole has formed a concept of an inclusive Islamic education curriculum that answers the challenges of an increasingly complex and dynamic era. So, inclusive values cover the shortcomings that are the basic character of existing Islamic religious education. So what happened in the Darul Amin Border Dayah, the emphasis was on the learning process by aligning the curriculum with the social life of students. Living in a pluralistic society, if it is emphasized on the textual teachings of Islam, will foster divisions in society. Islamic education needs to emphasize the attitude of life, moral values and appreciation of life that can help children develop their lives in a better direction. So for now, the Islamic religious education model must keep the teachings conveyed not emphasizing indoctrination which requires acting strictly on one choice. Islamic education material in its implementation does not tend to emphasize formal worship and is ritualistic and does not lead to appreciation in the social aspect. The curriculum at the Darul Amin Border Dayah is very protective of teaching which has an impact on the formation of a very pious personality in matters of ritual worship but 
not in the dimensions of social piety.

Basically, it is not arranged in a standard manner about inclusive Islamic education, but its implementation is bound by non-standard rules but has become a culture in the life of students and ustaz in the dayah. As students are sensitive to fate, suffering, difficulties experienced by others without seeing the difference. Based on this explanation, the Islamic education curriculum that is realized in learning at the Darul Amin Border Dayah that instills inclusive values is the following reasons:

1. The curriculum at the Darul Amin Border Dayah seeks to integrate in the learning process the value of diverse knowledge and life skills and harmonize with historical factors in people's lives.

2. Inclusive Islamic religious education is more focused on skills and solidarity and is closer to Allah SWT.

3. Instill love, help, tolerance, tolerance, respect for differences in actualizing the Islamic education curriculum

Based on this description, in its implementation the Islamic education curriculum that instills inclusive values is dynamic with the dynamics of society and the development of situations and conditions. So, inclusive Islamic education in the Darul Amin Border Dayah does not have a model in its standard form but in its realization in the daily lives of students. The curriculum construction that is implemented on students is dynamic contextual so that the students get fresh and not rigid knowledge. In general, in the Darul Amin Border Dayah environment, there are no standard rules and standard curriculum, but inclusive values are formed in an unwritten rule that must be obeyed.

The inclusive attitude that has been built in the Darul Amin Border Dayah is a culture that has been going on in a long process so that it becomes a non-standard rule but a necessity to obey. The concept of inclusion is an expression of freedom and respect for differences so that when dealing with a wider community coupled with religious diversity the students do not become rigid and stick to Islamic teachings. So this is what is most emphasized in the Darul Amin Border Dayah in inclusive education, namely the concept of social togetherness. The dayah environment is built by giving each student the right to receive equal treatment. So, inclusive education in the Darul Amin Border Dayah is inculcating inclusive values not only in the learning process in the dayah environment, but there is an unwritten curriculum that contains the teachings of life mingling with various differences. Meanwhile, in its implementation by involving all students and all dayah residents.

The ustaz and dayah managers have a role in strengthening the relationship between the students and the dayah environment, this role makes the ustaz and dayah managers a place to solve santri problems. The goal is to build an inclusive culture so that coexistence becomes a family, in line with this Islam pays great attention to ethics and tolerance in education. Particularly in an inclusive Islamic boarding school (pesantren), it can build intelligence in making changes for the community to convey the symbols of Islam. The community is basically a collection of various ethnicities and ethnicities and religions, in order to be able to act in order to live in harmony, human values are instilled for the students. Science in Islamic life is a very important and fundamental thing, but the most important thing is adab so that it will have a good impact so that the achievement of the goals of education itself is achieved. QS. Arrum: 23 has mentioned about inclusion is a necessity:

$$
\text { (QS. Arrum: 23) }
$$

22. And among the signs of his power is the creation of the heavens and the earth and different languages and colors of your skin. In fact, in that there really are signs for those who know.

The implementation of inclusive Islamic education in the Darul Amin Border Dayah gave birth to a progression in the dayah community because of a motivation to become quality. The daily life of the students in the dayah environment, the santri and the ustaz maintain intense communication, have a friendly attitude with the community, respect opinions, respect each other's weaknesses and strengths. Dayah is an environment that is part of society, so the students in the end become more sensitive to what is the problem in the community to immediately get a solution. For example, during holidays, students who return to their village are active in congregation to the mosque, participate in community religious activities, become imams, preachers and even take part in bathing, praying and burying the deceased. In youth and parent activities, the students also actively participate because in the dayah they are taught about leadership. Considering that the community of santri who study at the Darul Amin Border Dayah is not the majority Muslim, there is even a minority but it is not an obstacle for students to participate.

This is what gives an indication that in the Border Dayah Darul Amin built a dayah education system that makes santri inclusive through the learning process in the dayah. Basically, an attitude of tolerance towards diversity in the education process in dayah fosters an internal dialogue of diversity between students and the community. It cannot be denied that diversity in life in society is a necessity that involves various aspects. Islamic education cannot run alone, because Muslims live with a variety of diversity. Based on this, the mission of Islam is in line with the goal of education in the dayah, because by implementing the 
value of tolerance, respecting differences, helping each other in differences in Muslim society makes the environment of students both in society and in dayah that is rahmatal lil'alamin. The concept of inclusive Islamic religious education is not something new in dayah or in pesantren, but its implementation has been carried out by practitioners of Islamic education in the past. One of them can be seen from the formulation of the goals of Islamic education by Ibn Khaldun as follows (Walidin, 2003: 105):

1. Development of proficiency in a specific field,

2. Mastery of professional skills that are in line with the demands and needs of society,

3. Fostering good thinking by paying attention to the growth and development of the psychological potential of students.

So Islamic education is a development process that aims at maturity or maturity which is manifested based on the natural and social human conditions that enable students to face. This scientific concept is a problem in the process of human development, because every human being has a different potential and social life. If viewed from the power perspective, the problem faced lies in how the ustaz guides the students in facing the development process. So herein lies the importance of inclusive Islamic education so that students are able to live side by side and respect each other, not eliminate Islamic values itself. Based on this, the Darul Amin Border Dayah harmonizes through the vision of the dayah, namely as an educational institution that produces cadres of community leaders who educate and develop a generation of Muslim believers who are virtuous, healthy, knowledgeable, free-thinking and devoted to the community. Of course, in doing good in society without having the concept of inclusive Islamic education cannot be done because it will become rigid or can be rejected by the community.

The curriculum at the Darul Amin Border Dayah was formed with an integration between various general disciplines and religions, this needed to be done because it was in order to answer the problems faced by students. So, this integration in its implementation applies inclusive values, the values developed are:

1. The value of worship, namely all processes and thoughts are always recorded as worship

2. Ihsan value, namely the value developed on the basis of doing well to others.

3. Future value, namely to anticipate a better future

4. The value of mercy, namely the benefit of all mankind and the universe

5. The value of syiar, namely the development of education in society

\subsubsection{Darul Amin's Border Dayah Islamic Education: An Idea}

The concept of the highest goal of Islamic education is not only theoretically oriented, but runs a balance between theoretical and practical. Islamic teachings are basically scientific values that are in line with the practice of science. In essence, the purpose of Islamic education is not to separate knowledge, faith and righteous deeds. The educational goals to be achieved by reading, purifying, and teaching as mentioned in the verse are the same as devotion to Allah. In other words, Islamic education is philosophically oriented towards Islamic values targeting three dimensions of human relations;

1. Cultivating a balanced and harmonious relationship with God,

2. Forming a harmonious, harmonious and balanced relationship with the community,

3. Developing the ability to explore, manage, and utilize natural resources for the benefit of their welfare and the lives of others as well as for their ubudiyah interests to Allah SWT. Based on a harmonious attitude as well.

These three goals are the mission of Islam rahmatan lil al 'amin and this is the mission of inclusive Islamic education. The realization of inclusive Islamic education at the Darul Amin Border Dayah is inseparable from the vision and mission by continuing to emphasize a vision with cultural or environmental insight and community service. Differentiation of assistance or intervention given needs to be seen as an effort to provide educational services provided and not seen as an attempt to separate students from diversity into homogeneity. Knowing the concept of inclusive Islamic education can accommodate the needs of students to be able to interact with the dayah environment. So in this case, inclusive values get value on the affective which emphasizes understanding and practicing the values of Islamic teachings in the life of the dayah environment. It does not deny other educational institutions, but inclusive Islamic education is more appropriate as a forum to galvanize students effectively and efficiently. This is because the students stay 24 hours in the dayah environment under the supervision of the ustaz. If not, because inclusive values are formed, of course, the Darul Amin Border Dayah environment will often have misunderstandings.

The implementation of inclusive Islamic education is carried out independently by the ustaz, while the evaluation only focuses on the affective aspect because inclusive values emphasize more on practice. At least there are several things that are positive values in inclusive Islamic education in the dayah environment, including: 
1. Students practice Islamic values in daily life in the dayah environment so that they become habituation in the environment where they live

2. Generating a generation of emotionally intelligent, spiritual and tolerant values

3. Developing a religious culture by obeying the knowledge that has been taught by the ustazes and practicing the commands of Allah SWT.

4. Instilling in students to filter themselves from the influence of technology that destroys morals.

5. The application of an inclusive culture

Inclusive Islamic education in the Darul Amin Border Dayah is not stagnant, but developments are carried out along with the progress of society, various forms of activities are stipulated in the dayah curriculum. This subjective reality continues to be internalized in everyday life, because inclusion has a very broad meaning, so it can be externalized in the life of the students. The concept of inclusion in Islamic religious education can foster dialogue within religions and between religious communities, this is because differences are a common thing. The habit of managing diversity in the Darul Amin Border Dayah for students is certainly not something that is rigid when facing different beliefs in society. In articulating this idea, it is shown the power of control over the classical and modern intellectual treasures of Islam. So the concept of inclusion is manifested in the form of multiculturalism and religious pluralism which is a necessity that involves various aspects, the more that plays a role is education. Islamic education cannot work with a single group, because Muslims live in various diversity. Thus Islamic education must formulate an educational concept that produces students who can accept diversity.

Inclusion in Islamic education in the dayah environment is understood as a true linkage of diversity within ties of civility and a necessity for the safety of students, especially those who are part of society, among others through the mechanism of monitoring and balancing it produces. So as a sociological phenomenon, inclusion is a fact that cannot be denied, this points to the fact that the history of religion shows a plurality of traditions and variations. People's understanding of Islam can vary. This misconception is not only among Muslims who often view Islam with a single face, including in viewing pluralism. Islamic religious education must be able to respond to the situation by instilling and disseminating the Islamic concept of tolerance in society. This tendency of exclusivity needs to be constructed in the inculcation of more inclusive values, Islamic religious education that is carried out in the teaching process is not exclusive but develops an attitude of inclusiveness towards various cultural, religious, racial and other backgrounds, namely education that is open and accommodating against all religious pluralism.

Inclusive in Islamic education is conceptually and operationally in line with the objectives of the Islamic perspective. The concept of adab tends to emphasize more on improving the character or values of human life. The connection with Islamic education is to instill adab in students. Humans as individual beings, basically humans themselves develop and move towards perfection so as to give birth to good morals with indicators of honesty, tolerance, and love between people.

\section{Conclusion}

Inclusive Islamic education at the Darul Amin Border Dayah is integrated in the implementation of the dayah curriculum both the dayah curriculum, the formal curriculum, the informal curriculum and the nonformal curriculum. Inclusive values instilled in dayah daily life are the values of tolerance, togetherness, mutual assistance, respect for differences and leadership based on Islamic values. The essence of inclusive Islamic education in the Darul Amin Border Dayah is the leader of the ummah and the generation of Muslim believers who are highly virtuous, knowledgeable, free-thinking and devoted to society.

\section{References}

Daulay, Haidar Putra. (2001). Modernisasi Islam: Tokoh Gerakan dan Gagasan (Islamic Modernization: Figures of Movement and Ideas). Bandung: Ciptapustaka Media

Huberman, A. Michael. dan Mattew B. Milles. (1984). Data Management and Analysis Methods, New York: New York Press.

Kustawan, Dedy. (2012). Pendidikan Inklusif \& Upaya Implementasinya (Inclusive Education \& Its Implementation Efforts). Jakarta: Luxima

Munandar, Utami. (1999). Pengembangan Kreatifitas Anak Berbakat (Inclusive Education \& Implementation Efforts. Development of Talented Child Creativity). cet I. Jakarta: Rineka Cipta.

Moeleong, Lexi J. (2011). Metode Penelitian Kualitati (Qualitative Research Methods). Bandung: Rosdakarya.

Sunanto, Musyrifah. (2005). Sejarah Islam Indonesia (History of Indonesian Islam), Jakarta: Raja Grafindo Persada. 
Walidin, Warul. (2003). Konstelasi Pemikiran Ibnu Khaldun (Ibn Khaldun's Constellation of Thought). Lhokseumawe: Nadiya Foundation. 